Економічні науки: збірник наукових праць Луцького національного технічного університету. Серія “Регіональна економіка". Випуск 18 (71). Редкол.: відп. ред. д.е.н., професор Л.Л. Ковальська. Луцьк: ІВВ Луцького НТУ, 2021. 278 с.

УДК 339

Галазюк Н.М., к.е.н., доцент

Кулина О.

Луцький національний технічний університет

\title{
ВПЛИВ ТНК НА ФОРМУВАННЯ КОНКУРЕНТНОГО СЕРЕДОВИЩА КРАЇН СВІТУ
}

В сучасних глобальних умовах ТНК здійснюють все більше впливають на світову економіку, розвиток якої певним чином визначається особливостями їх розвитку. В статті розкрито роль та місце ТНК в системі міжнародних економічних відносин, розглянуто сучасні та стратегії діяльності ТНК та форми впливу на формування та розвиток конкурентного середовища, як у світовій економіці, так і в окремих країн. Доведено, що на сьогодні, ТНК через ПІІ, постійно посилюють свій вплив, як на розвиток міжнародних економічних відносин, так і на конкурентоздатність національних економік.

Ключові слова: транснаціональна корпорація, прямі іноземні інвестиції, конкурентні переваги, міжнародні економічні відносини, світове господарство.

\section{Galazyk N., Kulyna O.}

\section{THE INFLUENCE OF TNCS ON THE FORMATION OF A COMPETITIVE ENVIRONMENT OF COUNTRIES}

A characteristic feature of the current stage of development of the world economic system is the rapid development of the transnational sector, TNCs are also a product of the system of international economic relations, which today are developing rapidly and themselves represent a powerful mechanism for influencing them.

Actively influencing international economic relations, TNCs form a system of fundamentally new relations, modify their existing forms. Modern TNCs, their specific management, economic activity, organizational forms are of scientific interest to a number of researchers.

The behavior of TNCs is constantly changing, their impact on new economic world economic processes is ambiguous, so there is a need for in-depth study of such organizational structures at the present stage of the world economy, as well as defining strategic directions of TNCs in the context of increasing competitiveness.

The current competitive environment is dynamic, due primarily to the rapid pace of globalization, uneven socio-economic development of countries, and as a result there is fierce competition between businesses, regions and countries. Obviously, the main goal of each country's government in the first place is a high standard of living, and the main tool to achieve this goal is the country's constant 
Економічні науки: збірник наукових праць Луцького національного технічного університету. Серія “Регіональна економіка". Випуск 18 (71). Редкол.: відп. ред. д.е.н., професор Л.Л. Ковальська. Луцьк: ІВВ Луцького НТУ, 2021. 278 с.

economic growth, through continuous improvement of national business efficiency, increasing foreign economic activity, and increasing the competitiveness of the national economy.

Characteristic features of the current state of the world economy are largescale operations conducted by TNCs, which are manifested in the constant growth of foreign branches and parent companies. In recent years, the growth rate of global gross investment has halved, in contrast to FDI.

FDI creates joint ventures and entire strategic alliances, and the characteristic feature of such entities is the merger of several small companies that will be able to compete with key market leaders. The main tools for increasing the competitive relations of TNCs in modern conditions are large-scale FDI and financing of innovative technologies and R\&D. Competitive advantages of TNCs in the world market are the accumulation of financial resources, innovation and technological developments that are introduced into manufacturing enterprises, resulting in constant updating of products and a wide range of services, as well as the accumulation of significant labor potential.

Key words: transnational corporation, foreign direct investment, competitive advantages, international economic relations, world economy.

\section{Галазюк Н.Н., Кулина О. \\ ВЛИЯНИЕ ТНК НА ФОРМИРОВАНИЯ КОНКУРЕНТНОЙ СРЕДЫ СТРАН МИРА}

В современных глобальных условиях ТНК осуществляют все больше влияют на мировую экономику, развитие которой определенным образом определяется особенностями их развития. В статье раскрыта роль и место ТНК в системе международных экономических отношений, рассмотрены современные и стратегии деятельности ТНК и формы влияния на формирование и развитие конкурентной среды, как в мировой экономике, так и в отдельных стран. Доказано, что на сегодня, ТНК через ПИИ, постоянно усиливают свое влияние, как на развитие международных экономических отношений, так и на конкурентоспособность национальных экономик.

Ключевые слова: транснациональная корпорация, прямые иностранные инвестиции, конкурентные преимущества, международные экономические отношения, мировое хозяйство.

\section{Постановка проблеми у загальному вигляді і її зв'язок} 3 важливими науковими та практичними завданнями. Характерною рисою сучасного етапу розвитку світової господарської системи є стрімкий розвиток транснаціонального сектору, активна діяльність ТНК зумовлює швидкі темпи та масштаби розвитку глобалізації. ТНК стають ключовою ланкою 
Економічні науки: збірник наукових прачь Луиького національного технічного університету. Серія "Регіональна економіка". Випуск 18 (71). Редкол.: відп. ред. д.е.н., професор Л.Л. Ковальська. Луиьк: ІВВ Луцького НТУ, 2021. 278 с.

у розвитку міжнародних економічних відносинах, у процесах поглиблення виробничо-господарських зв'язків між суб' єктами господарювання країн світу та займають вагоме місце у системі сучасного світового ринку.

ТНК одночасно $є$ продуктом системи міжнародних економічних відносин, які сьогодні розвиваються швидкими темпами та самі представляють могутній механізм впливу на них. Активно впливаючи на міжнародні економічні відносини ТНК формують систему принципово нових відносин, видозмінюють сформовані їх форми. ТНК посилюють інтернаціоналізацію світового господарства, а своєю виробничогосподарською діяльністю поєднують національні та регіональні ринки товарів та послуг. Сьогодні практично усі процеси, що відбуваються на міжнародній арені не проходять без участі ТНК.

Аналіз останніх досліджень, у яких започатковано вирішення проблеми. ТНК створили економічну базу для глобалізації світового економічного простору, також вони відіграють провідну роль у НТП та здійснюють вплив на конкурентне середовище країн світу. Сучасні ТНК, їх специфіка управління, господарська діяльність, організаційні форми представляють науковий інтерес цілого ряду дослідників. Серед зарубіжних і вітчизняних авторів, які досліджували ТНК, слід назвати Рогач О., Сорока I., Макарчук К., Матросова I., Ткаченко Д., Качур А., Могилко Д. та ін. Разом з тим, поведінка ТНК постійно змінюється, їх вплив на нові економічні світогосподарські процеси неоднозначний, тому виникає необхідність поглибленого вивчення діяльності таких організаційних структур на сучасному етапі світової економіки, а також визначення стратегічні напрямки діяльності ТНК в контексті зростання конкурентоспроможності приймаючих країн.

Цілю даної статті $є$ визначення основних інструментів діяльності ТНК з метою забезпечення конкурентних переваг економік приймаючих країн. 
Економічні науки: збірник наукових праџь Луцького національного технічного університету. Серія "Регіональна економіка". Випуск 18 (71). Редкол.: відп. ред. д.е.н., професор Л.Л. Ковальська. Луцьк: ІВВ Луцького НТУ, 2021. 278 с.

Виклад основного матеріалу дослідження 3 повним обгрунтуванням отриманих наукових результатів. Сучасне конкурентного середовища має динамічний характер, це пов'язано насамперед швидкими темпами глобалізаційних змін, нерівномірним соціально-економічним розвитком країн, i як наслідок відбувається гостра конкурентна боротьба між суб'єктами господарювання, регіонами та країнами.

Очевидно, що основна мета влади кожної країни в першу чергу, це високий рівень життя населення, а головним інструментом досягнення такої цілі $є$ постійне економічне зростання країни, через постійне підвищення показників ефективності національного бізнесу, нарощення темпів розвитку зовнішньоекономічної діяльності, та підвищення рівня конкурентоспроможності національної економіки. Остання дедалі більше залежить від ступеня ії залучення до «глобальних комплексів, які формуються значною мірою на основі внутрішньофірмового поділу праці ТНК та їхніх активних транскордонних операцій» [1, с. 61].

Сучасний міжнародний ринок висуває жорсткі вимоги щодо конкурентоспроможності. Міжнародний бізнес стикається iз складними завданнями в системі оподаткування та ціноутворення, курсу валюти, адаптацією товарів до смаків та уподобань іноземного споживача. Левова частка міжнародного бізнесу припадає на ТНК. Саме тому, основними принципами «конкурентоспроможності ТНК $є$ конкурентні переваги, які відбуваються 3 покращенням технологій, впровадженням нововведень, фінансуванням НДДКР. Також конкурентні переваги часто створюються у ринкових нішах, до яких конкуренти не виявляли зацікавленості через ї незначну прибутковість та малу ємність на момент засвоєння» [2, с. 38].

ТНК беруть участь у конкурентній боротьбі на світовому ринку, і у своїй діяльності зобов'язані дотримуються глобальної стратегії розвитку. Глобальна стратегія діяльності ТНК вирішує два основні питання:

1) доцільно враховувати можливості окремих країн, щодо раціонального розміщення виробничих потужностей; 
Економічні науки: збірник наукових праџь Луцького національного технічного університету. Серія "Регіональна економіка". Випуск 18 (71). Редкол.: відп. ред. д.е.н., професор Л.Л. Ковальська. Луиьк: ІВВ Луиького НТУ, 2021. 278 с.

2) єдиною метою нарощення обсягів реалізації - це організація та координація роботи усіх ланок компанії.

На сьогоднішній день відбуваються зміни в поняттях та підходах до стратегічного управління ТНК, основною причиною таких змін $\epsilon$ необхідність вибору для корпорації найбільш ефективних конкурентних стратегій. М. Портер пропонує обрати корпоративну стратегію «на основі аналізу позиціонування тієї чи іншої ТНК на ринку, диференціації вироблених товарів і цінових переваг» [3].

Відомо, що «базовою теорією міжнародного виробництва i існування самих ТНК як основних його суб'єктів і ПІІ як засобу його фінансування стала еклектична парадигма Дж. Даннінга, яка успішно використовується для аналізу основних конкурентних стратегій ТНК» [4, с. 56]. Дана теорія виділяє такі три групи факторів, що надають конкурентні переваги ТНК, як:

- переваги власності;

- переваги локації;

- переваги інтернаціоналізації.

Сучасні ТНК є рушійною силою економічного зростання як окремо взятих країн, так і світового господарства вцілому, оскільки вони $є$ ключовим джерелом підвищення рівня конкурентоспроможності національної економіки приймаючої країни.

Характерними ознаками сучасного стану світової економіка $є$ масштабні операції, які проводяться ТНК, що проявляються у постійному зростанні закордонних філій та материнських компаній. За останні роки темпи та обсяги росту світових валових інвестицій скоротилися вдвічі, на противагу до ПII. «Мережа філій ТНК по всьому світі розростається досить швидкими темпами, адже нині близько $80 \%$ світових платежів пов'язані 3 внутрішніми трансакціями ТНК. Про зростання масштабів транснаціоналізації світової економіки свідчить те, що сума внутрішнього та зовнішнього нагромаджених обсягів прямих іноземних інвестицій досягла $1 / 5$ світового ВВП, експорт закордонних філій ТНК становить $1 / 3$ світового 
Економічні науки: збірник наукових праџь Луцького національного технічного університету. Серія "Регіональна економіка". Випуск 18 (71). Редкол.: відп. ред. д.е.н., професор Л.Л. Ковальська. Луиьк: ІВВ Луиького НТУ, 2021. 278 с.

експорту, а ВВП, вироблений за рахунок закордонних філій, складає 7\% світового ВВП» [5, с. 56].

За рахунок ПІІ утворюються спільні підприємства та цілі стратегічні альянси, характерною ознакою таких утворень $\epsilon$ об'єднання декількох невеликих компаній, які зможуть конкурувати з ключовими ринковими лідерами.

Висновки. Основними інструментами нарощення конкурентних відносин ТНК в сучасних умовах є масштабні ПІІ та фінансування інноваційних технологій та НДДКР. Конкурентними перевагами діяльності ТНК на світовому ринку $\epsilon$ акумулювання фінансових ресурсів, інноваційних та технологічних розробок, які запроваджуються у виробничі підприємства, як наслідок проходить постійне оновлення асортименту продукції та різноманітного спектру послуг, а також акумуляція значного трудового потенціалу.

\section{Список бібліографічного опису}

1. Транснаціоналізація i конкурентний розвиток національних економік: теорія i практика країн, що розвиваються: монографія / Л.В. Руденко-Сударєва, О.М. Мозговий, В.В. Токарь та ін. - Вид. 2-ге, доп. К. : KHEУ, 2015. $270 \mathrm{c}$.

2. Портер М.Е. Конкурентное преимущество: как достичь высокого результата и обеспечить его устойчивость. - М.: Экономическая наука, 2005. $167 \mathrm{c}$.

3. Портер М. Международная конкуренция. URL: https://f.ua/alpinapablisher/mejdunarodnaja-konkurencija-konkurentniye-preimusheestva-stran. html

4. Ткаченко Д.О. Аналіз особливостей сучасних теоретичних концепцій формування та функціонування ТНК. Причорноморські економічні студії. Економічний науково-практичний журнал. Випуск 11. 2016 p. C.55-59. URL: http://bses.in.ua/journals/2016/11-2016/14.pdf

5. Качур А.В., Могилко Д.М. ТНК та їх роль у сучасних міжнародних економічних відносинах. Економіка i суспільство. Світове господарство i міжнародні економічні відносини. Електронний журнал. Випуск №19. 2018. C.55-62. URL: http://economyandsociety.in.ua/journals/19_ukr/9.pdf

\section{References}

1. Transnatsionalizatsiia i konkurentnyi rozvytok natsionalnykh ekonomik: teoriia i praktyka krain, shcho rozvyvaiutsia: monohrafiia / L.V. RudenkoSudarieva, O.M. Mozghovyi, V.V. Tokar ta in. - Vyd. 2-he, dop. K. : KNEU, 2015. 270 s. [in Ukrainian].

2. Porter M.E. Konkurentnoe preymushchestvo: kak dostych vыsokoho rezultata y obespechyt eho ustoichyvost. - M.: Эkonomycheskaia nauka, 2005. $167 \mathrm{~s}$. 
Економічні науки: збірник наукових праџь Луцького національного технічного університету. Серія “Регіональна економіка". Випуск 18 (71). Редкол.: відп. ред. д.е.н., професор Л.Л. Ковальська. Луцьк: ІВВ Луиького НТУ, 2021. 278 с.

3. Porter M. Mezhdunarodnaia konkurentsyia. URL: https://f.ua/alpinapablisher/mejdunarodnaja-konkurencija-konkurentniye-preimusheestva-stran. html

4. Tkachenko D.O. Analiz osoblyvostei suchasnykh teoretychnykh kontseptsii formuvannia ta funktsionuvannia TNK. Prychornomorski ekonomichni studii. Ekonomichnyi naukovo-praktychnyi zhurnal. Vypusk 11. 2016 r. S.55-59. URL: http://bses.in.ua/journals/2016/11-2016/14.pdf [in Ukrainian].

5. Kachur A.V., Mohylko D.M. TNK ta yikh rol u suchasnykh mizhnarodnykh ekonomichnykh vidnosynakh. Ekonomika i suspilstvo. Svitove hospodarstvo i mizhnarodni ekonomichni vidnosyny. Elektronnyi zhurnal. Vypusk №19. 2018. S.55-62. URL: http://economyandsociety.in.ua/journals/19_ukr/9.pdf. / [in Ukrainian].

DOI: https://doi.org/10.36910/2707-6296-2021-18(71)-3

УДК 332.1

Дзюбинська О.В., к.е.н., ст. викладач

Дзюбинський А.В., к.е.н., доцент

Голодюк Г.І., к.т.н., доцент

Луцький національний технічний університет

\section{ІМПОРТ ВІДХОДІВ В УКРАЇНІ: ПРОБЛЕМА ЧИ ПЕРСПЕКТИВИ}

В статті розглянуто стан справ у сфері переробки твердих побутових відходів (ТПВ). Відзначається, що не дивлячись на величезні щорічні додаткові обсяги сміття на полігонах, українські переробні підприємства вимушені імпортувати сировину. Висновок з цієї ситуації один: наші ТПВ низької якості та не можуть повноцінно бути використані у переробці. Тобто імпорт $є$ вимушеним. Сдиним виходом 3 ситуації ми бачимо у якомога більшому охоплені регіонів України роздільним збором твердих побутових відходів.

Ключові слова: імпорт, відходи, сміття, регіон, роздільний збір.

\section{Dziubynska O., Dziubynskyi A.,Golodyuk G. WASTE IMPORTS IN UKRAINE: PROBLEM OR PROSPECTS}

Solid waste recycling is a rather complex process that requires not only significant financial investments, but also deal it desire. 